\title{
The Optical Work of Charles Tulley
}

\author{
By H. C. KING, Esq. \\ ABSTRACT of Paper read on 7th June, 1949
}

Charles Tulley, a London optician of the first half of the 19th century, played a small but effective part in the development of the achromatic telescope.

When the Astronomical Society received in 1822 a 2-inch blank of flint glass from Guinand, Tulley, already a Member of the Society, was invited to work it into a concave component for an achromatic doublet. The Society was impressed by the performance of the glass but not with its size. When a $7 \frac{1}{4}$-inch blank arrived from Guinand, Tulley was asked to mate it with a convex crown. This he effected to the Society's satisfaction, but Tulley's charge of $£ 200$ for the work was considered excessive. Fortunately, the Rev. W. Pearson bought the glass and so prevented what might have been a serious dispute. Of 6.8 inches clear aperture, this object-glass remained Tulley's largest. From Pearson the telescope passed to Capt. W. Noble and then, in 1855, to L. Prince, who erected it at the Crowborough Hill Observatory.

Tulley made several fine object-glasses for Sir James South. In 1822, Tulley completed a 31-inch, F/14 aplanatic doublet based on John Herschel's computation-the first glass of its type. South received two large (for those times) flint blanks from Paris ; these Tulley used for the concave components of a 5-inch and a 5.9 inch object-glass. South considered that the former was the finest of its type. The latter he sold to W. H. Smythe, author of the "Cycle of Celestial Objects".

Tulley competed with Cary, Watson and T. and W. Harris in the manufacture of reflecting telescopes. William Kitchener spoke highly of the performance of his 7-inch Tulley Gregorian and 15-inch Cassegrainian. From the undated price list of Tulley's reflectors which Kitchener published in 1825, it appears that Tulley marketed 9-inch aperture Gregorians and 10-inch aperture Newtonians.

We know little of Tulley's method of glass-working. He appears to have adopted the time-honoured and wasteful trial and error methods of his predecessors. His workshop was at Territt's Court, Islington, where, assisted by his two sons, he spent, in company with George Dollond, Sir John Herschel and Sir James South, many hours testing object-glasses on close double-stars. He died in 1832 or 1833 . The business continued under William Tulley, the first optician to market achromatic microscope objectives, but ceased upon the death of the younger son, Thomas Tulley, in 1846.

\section{The Anatomy of Geology}

\section{BY DR. S. I. TOMKEIEFF}

\section{ABSTRACT of Paper read on 24th October, 1949}

The word "anatomy" in Greek means " dissection". In the present discussion " anatomy of geology" stands for a logical dissection of the science of geology under the guidance of historical method, with the object of discovering its fundamental framework or structure. Such an inquiry differs from the one entitled "philosophy of geology" which is often applied, not to the analysis of the logical structure of the science of geology, but to the general discussion of the objects of the science of geology. However important such 